\title{
The Economic Experimentation of Nembula Duze/Ira Adams Nembula,
} $1845-1886$

\author{
Eva Jackson \\ University of KwaZulu-Natal
}

\begin{abstract}
:
This paper gives a short biography of Ira Adams Nembula, the Natal sugarcane manufacturer. Nembula's business and his family have been often mentioned but not fully described before in accounts of Natal's nineteenth-century economy and mission stations. This paper draws on historians' narratives and missionary writings on Nembula from the American Board of Commissioners for Foreign Missions (American Board), and incorporates information from the archives of the Secretary for Native Affairs (SNA), to look at the life of a man who was described by missionaries as one of the "first fruits" or very first converts to Christianity in Natal, and was a preacher, a pioneering sugarcane producer, and also a transport rider. The paper outlines Nembula's and his mother Mbalasi's position and portrayal as initial converts in the American Board, his sugar milling business, and his plans to farm on a large scale. Nembula's steps towards buying a large tract of land left an impression in the procedures government followed around black land ownership; and may also have contributed to the formulation of colonial laws around black land ownership and exemption from "native law". Nembula's story in many ways exemplifies the amakholwa experience of what Norman Etherington has called "economic experimentation" and the frustration of that vision.
\end{abstract}

Nembula kaDuze, or Nembula Makhanya, was at one time an important figure in the social and economic world of the American Board of Commissioners for Foreign Missions (American Board) established in Natal from 1835. After his mother Mbalasi Makhanya, Nembula was the second person in Natal to convert to Christianity through the Board's mission work. Nembula's sugar milling enterprise based at Adams mission station was the first black-owned mill in the country. His son John Mavuma Nembula was the second black doctor in southern Africa, travelling to America with the support of the American Board and qualifying there, later to come back to Natal. For both Nembula and his son John, ambitions and achievements that were at the time considered enormous did not ultimately hold off poverty. Their lives have left a stamp in missionary histories, oral histories, and contemporary memorialisations especially in the wider area of Adam mission. This paper aims to outline the life of Nembula, and how his initiatives were received by the state and within the mission.

In 1846 Natal, Nembula Makhanya was a young man of about twenty. He had married two women, with whom he was living at Amanzimtoti, near the mission station run by $\mathrm{Dr}$ Newton Adams. Nembula's mother Mbalasi was also on the station, a widow of the Makhanya chief. ${ }^{1}$ Adams' station was one of several that the American Board had

$1 \quad$ Nembula's father, Mbalasi's husband, was Duze Makhanya, who was according to different reports killed by Shaka or by Dingane. For a discussion of Mbalasi's and her contemporaries' experiences of royal widowhood, see E Jackson, Chapter 2 "Wife of the Former Chief: Dalida Dube, Mbalasi 
established since the mid-1830s, when they arrived as the very first missionary society to begin staking a claim to the 'missionary field' north and south of Port Natal.

Mfazimuni, one of Nembula's two wives, had been a student with him at the day school run by Newton Adams at Umlazi. ${ }^{2}$ She was the eldest daughter of another prominent family on a neighbouring mission station, Inanda. ${ }^{3} 1846$ was a significant year for the American mission because in this year Mbalasi was baptised, followed two months later by her son Nembula choosing to leave his second wife and become a monogamist, and marry Mfazimuni by Christian rites. ${ }^{4}$

The ceremony was a double one - another (unknown) man at Amanzimtoti took the same step on the same day. Dr Newton Adams helped to negotiate the "comforting" of the two wives who had been discarded. ${ }^{5}$ A few women came from a little way away to attend the wedding and were likely provided with some of the "plain calico dresses" that Newton Adams kept that year, for congregants to put on during services and hand back to him afterwards at the door of the church. ${ }^{6}$ After the wedding ceremony, Sarah Adams went to some trouble to recreate the "civilised" niceties she missed, and "gave a wedding reception at which she supplied the native guests with coffee and cake made from half a bushel of Indian meal to which a little sweetening and a few raisins had been added". 7 The weddings thus played out in strange, even surreal contrast to the social schism and unease that surrounded them. They caused a stir. Around the station and elsewhere, there was "considerable discussion... and among some, strong antipathy." 8

Then in May 1847, Nembula and Mfazimuni were baptised as Christians. His name was changed from Nembula Makhanya to "Ira Adams Nembula" and hers to "Laura Nembula": Adams had named his second and third converts after his brother and his sister, who lived in New York. This striking decision, to recreate a form of family and establish more knowable personal frameworks and networks using the names of missionaries' actually existing family and friends, was to be repeated many times in Natal. While the rationales of individual converts and missionaries in such moments of naming of course varied greatly, the baptism of Nembula and Laura was the first instance

\footnotetext{
Makhanya, and meanings of widowhood and conversion at Inanda and Amanzimtoti, 1840-1860", in Four Women, Four Chiefships: Case studies in the divergent choices and negotiations with power of Amakhosikazi in nineteenth-century Natal (forthcoming MA dissertation, UKZN).

2 Mfazimuni also appears in SNA records as Laura. Mfazimuni is the name that was used by her children. PAR MSCE ), 38/190, Death notice of Nomavivi Nembula (surviving spouse, Norman Nembula), 1910 .

3 The views of Mahlathi: writings of A.W.G.Champion, M.W. Swanson (ed.) (University of Natal Press, 1982). 59

4 Shiels , Newton Adams, 29; American Board of Commissioners for Foreign Missions (ABCFM) 15.4 , Vol. 4., Newton Adams to Rufus Anderson, 1 October 1847.

ABCFM 15.4, 4, Adams to Anderson, 1 October 1847.

Shiels, Newton Adams, 30.

Missionary Herald, April 1847. Letter from J.C. Bryant, September 1846. Quoted in Shiels, Newton Adams, 64.

$8 \quad$ Missionary Herald, April 1847. Letter from J.C. Bryant, September 1846. Quoted in Shiels, Newton Adams, 64.
} 
in Natal of what became a patterned, now peculiar attempt to delimit strangeness, and forge links and belonging. ${ }^{9}$

The idea of converts' inclusion in the missionary family is a strong thread running through American Board records, and Nembula and his mother were possibly the first to enter into what Newton Adams called the "family system", a practice which spread from the Umlazi station to others in southern Africa and many different fields of American Board work around the world. This can be broadly described as a system in which missionaries secured with incentives the labour of people who came to live in or near the missionary home, most often young men, who were prospective preaching assistants and were educated within the missionary household. ${ }^{10}$ In Nembula's case, he and Mbalasi lived on or near the mission station from about 1837. He was one of three children who lived with Sarah and Newton Adams in this early stage of the mission station's life. The Adamses briefly vacated it in 1838-1839 during the conflict between Dingane and the Voortrekkers, and when they returned, six more young children came to join the household, and Nembula was apprenticed to Newton Adams and promised a cow and a calf if he was still with the missionary at the age of twenty-one. ${ }^{11}$ At the Methodist station at Edendale in Natal, a similar arrangement existed. The Allisons, who were the missionaries there until they were pushed out of the community in 1861, usually had up to "30 children and youths living with them". ${ }^{12}$ Sheila Meintjes refers to this system as one of "masked" exploitation, which set up the male missionary as both "'kin' and 'employer'... albeit paternal in his dealings”. 13

This entry of Mbalasi and Nembula into the missionary circle took on an added significance because of their connection to the Makhanya nobility (the Makhanya were related to and subject to the Qwabe). Norman Etherington has shown how Nembula and his cousin Musi, ruler of the Qwabe, in Natal from the late 1840s, exemplify a drastic divergence within one family. ${ }^{14}$ The two men, and their children, were headed in entirely different directions - on one hand the resuscitation of the Qwabe royal house and all its homesteads and wealth - and on Nembula's side, a Christian life and a foothold in capitalist production; and a son, John Mavuma Nembula, who qualified in Chicago to

\footnotetext{
$9 \quad$ See Forthcoming JNZH, Meghan Healy and Eva Jackson, “The Politics of Naming and the Possibilities of Home on American Zulu Mission Stations in Colonial Natal”.

$10 \quad$ Christofersen. Adventuring With God. 28; Interview with N. Makhanya. Weds $28^{\text {th }}$ November. 2007. 11: 40. The Voortrekkers also took African children as apprentices and, while the great differences between the two are clear (capture on the one hand and the offering of incentives on the other) both involved a wish to secure labour. Colin Bundy. The Rise and Fall of the South African Peasantry. (Cape Town: David Philip, 1979) 167
}

$11 \quad$ William Ireland. Jubilee of the American Mission in Natal, 1835-1885 (Horne, 1886) 42; Ross Shiels. Newton Adams, 1835-1851. (Unpublished Honours Dissertation, University of Natal, 1963).14 $12 \quad$ Sheila Meintjes. "Family and gender in the Christian community at Edendale, Natal, in colonial times.” In Cherryl Walker (ed.) Women and Gender in Southern Africa to 1945. (Cape Town: David Philip, 1990) 125-145. 129, 132.

\footnotetext{
13 Meintjes, "Family and gender in the Christian community at Edendale”, 133.

14 Norman Etherington, Preachers, Peasants and Politics, Preachers, Peasants and Politics in South East Africa, 1835-1880: African communities in Natal, Pondoland \& Zululand, 8-9.
} 
become the second black doctor in southern Africa. Musi's wealth and prestige grew up from nothing because of the support of what remained of the Qwabe royal household. His wealth lay primarily in the prosperity and number of his royal homesteads, the agricultural labour of his wives, the lobola royal daughters would bring in, and tributes from subjects. On Nembula's side, a Christian wedding was a major shift, a decision to embrace a set of new moral and productive strictures and possibilities.

At some point after his baptism in 1847, according to one of his sons, as a young man Nembula was sent to study in Cape Town, which missionary descriptions of him do not mention. ${ }^{15}$ He certainly worked as a preaching assistant for the American Board as a young man, and it is likely that he was, like many amakholwa, farming to produce a market surplus for meeting living needs and taxes. He may have started at this time the transport-riding that brought him an income later in the 1880 s.

In the mid-to-late 1850s, about 175000 acres of land were formally allocated to a number of different mission societies. ${ }^{16}$ Most of the Mission Reserves thus created lay within or adjacent to the Locations. Freehold title deeds were issued to individuals on Mission land, and the Nembula got a plot at Amanzimtoti probably in about 1856 or a little later. Nembula and Mfazimuni's son Henry was born in the early or mid 1850s, Norman Sydney in 1857 (who assisted James Stuart, the oral historian), and John Mavuma in 1861. ${ }^{17}$ They had ten children, and most of them applied for exemption from the operation of native law - although it is notable that Nembula himself did not apply for an exemption. ${ }^{18}$

From 1865 into the late 1870s, Nembula and his business partner, Ncaijana Mkhwanazi, embarked on a major venture at Amanzimtoti. Nembula was about thirty-seven when they began planning their sugar mill. The partners "[took] the lead on the country in the work of starting by native enterprise alone the first establishment which deserves to be called a manufactory". 19

15 KCC, Uncat. MSS, in “Steel Drawers”, 8639, Ephraim Nembula to Killie Campbell, c.1940.

16 The area to be allocated to the missions was initially planned to be bigger. The Locations Commission of 1846 to 1847 marked an early period of close cooperation between the American missionaries and the colonial government. After this, tension arose, as the government reduced the locations from the initial extent recommended by the Commission and initially accepted by the LieutenantGovernor. Settlers' shrill objections to land being allocated to Africans, and colonial reluctance to spend on the Locations, whittled away at the missionaries' intentions for these areas.

$17 \quad$ References to Norman Nembula facilitating interviews, translating, and giving evidence himself are scattered throughout the volumes of the James Stuart Archive (C de B Webb, J Wright, The James Stuart Archive of Recorded Oral Evidence Relating to the History of the Zulu And Neighbouring Peoples (Killie Campbell Africana Library Reprint Manuscript Series)

18 Applications for exemption from Native Law. John Mavuma Nembula: PAR SNA I/1/104

94/1888.; Norman Sidney Nembula:PAR SNA I/1/148 1205/1891

19 American Board of Commissioners for Foreign Missions (ABCFM) 15.4, 7, David Rood to Rufus Anderson, July 31, 1865, quoted in Etherington, Preachers, Peasants and Politics, 120-121.

I have been unable to pin down information on Nembula's business partner. Cayijana's other name was either Mkhwanazi (according to Ephraim Nembula’s letter) or possibly Zulu. 
This was the second amakholwa sugar milling project, and was envisioned on a large scale; Nembula and Ncaijana planned to move into production for the international market. Their experience can be taken as fitting into or illustrating the analysis of a "Natal peasantry" that moved into widespread agricultural production and entrepreneurial activity by the 1860 s, and saw these intentions frustrated. ${ }^{20}$

By looking into SNA records on the Amanzimtoti mill it is possible to get a window onto the production and the hopes hanging on it for the partners, who played a notable role in the fever surrounding sugar production in Natal and at a time when the possibility of sugar profits drew in the hopes and the capital of many people.

The ground in Natal was contested. Henry Slater, Colin Bundy, Norman Etherington and others during and since the 1970s have debunked the view of two separate economies in nineteenth century Natal. Slater argued that the picture was not one of separately operating African subsistence and white commercial agriculture, but instead involved complex economic interconnection, in the exercise of "economic choices". ${ }^{21}$ Bundy foregrounded the successes of black producers, (though giving Natal a less specific treatment), showing clearly that in the second half of the nineteenth century, African Christian peasant farmers and traders in South Africa provided considerable competition for disgruntled white farmers, (who also felt this diverted labour from their farms). Norman Etherington and Sheila Meintjes closely document the economic "experiments" of particular communities of amakholwa in Natal, describing the role of the government in the accelerating erosion of African economic gains, toward the turn of the century. ${ }^{22}$

The story of Nembula's sugar production is interlinked with that of the sugar growing and milling on the neighbouring American Board station at Umvoti which has been detailed by Vukile Khumalo. ${ }^{23}$ The Umvoti production was mostly funded by the colonial government; missionaries and amakholwa jointly appealed to the government for help establishing a mill as sugarcane cultivation was burgeoning on the mission station. Though his experience differed from that at Umvoti in many respects, as at Umvoti the first few years of Nembula's business showed the risks he was prepared to take, and his hopes of great success.

Sugar-growing was so popular in Natal from the mid 1800s that it was likened to a malady, a "fever". By 1861 it had began to spread as a response to the global sugar boom that lasted roughly from 1854 to $1866 .^{24}$ This boom was to some extent stifled, and many

\footnotetext{
20 See Etherington, Preachers, Peasants and Politics; Bundy, The Rise and Fall of the South African Peasantry.

${ }_{21} \quad$ Henry Slater,“The Changing Pattern of Economic Relationships in Rural Natal, 1838-1914”, in Shula Marks and Anthony Atmore: Economy and Society in Pre-Industrial South Africa. (London: Longman, 1980), 158.

22 Etherington, Preachers, Peasants and Politics.

23 C.V. Khumalo. Politics, Power and Production: An historical investigation of African Sugar Cane Production at Umvoti mission Reserve 1844-1905, (MA Thesis, University of Natal, 1997).

$24 \quad$ P. Richardson. "The Natal Sugar Industry in the Nineteenth Century”, in William Beinart, Peter Delius and Stanley Trapido (Eds.) Putting a Plough to the Ground: Accumulation and Disposession in Rural South Africa 1850-1930.
} 
growers' and producers' experiences profoundly shaped (including Nembula's), by the economic depression that hit Natal in the late 1860s. ${ }^{25}$

From the 1860s, African farming collectives emerged in response to sugar, mainly from within amakholwa communities. Entrepreneurs aimed to fit into a burgeoning capitalist, colonial economy, competing with white farms. The sugar crop behind the "craze" afflicting Natal was alluring but potentially ruinous; it offered the incentive of huge profits but drank up capital. Etherington and Khumalo describe the increase in numbers of sugarcane farms and milling concerns initiated by African farmers: from missionarysupported beginnings at Umvoti to Nembula and Ncaijana's spearheading at Amanzimtoti, to Imfume, and onwards in a "sugar-growing craze which crossed denominational lines". ${ }^{26}$

In the 1860s, more families on the Umvoti location began to grow sugar cane. In 1861 the American missionaries, in consultation with growers, decided to petition the government for help in setting up a mill. When the deal was finalised, the government purchased a mill from England, partly by using some of the 5000 pounds set aside to help fund projects in the locations. A government-appointed manager would be placed over the mill, and in addition to their other involvement in sugar production the growers of the mission station would supply cane. ${ }^{27}$

Nembula and his business partner Ncaijana were inspired by Umvoti to start production in 1864. They did not, however, order their machinery from England as the Umvoti planters and Grout had done. The two partners found a mill in Natal and took on a load of personal debt in buying and running it. They bought the machinery, and built a mill, on the understanding that friends of Nembula's who were growing sugarcane at Umvoti would help to finance the venture. However, difficulties experienced at Umvoti placed a temporary block in the path of the Amanzimtoti production; Nembula, Ncaijana, and the missionary David Rood had to negotiate a web of debt to find a solution.

In 1864, Ira Nembula and Ncaijana Mkhwanazi bought the steam mill for crushing sugarcane. Ncaijana is almost entirely silent in government records; it is Nembula who is always referred to as an initiator, and applicant for financial help. For example, Robert Mann, the Visitor of Native Institutions, wrote that "Nembulo was led to this spirited proceeding in consequence of having witnessed the result of the working of the Government Sugar Mill at the Umvoti Mission Station”. ${ }^{28}$

There was often strong competition amongst the earliest sugar farmers on the south coast and disagreement in retrospect over who was the first to start growing, and who first procured cuttings that others used. ${ }^{29}$ Nembula's claim to precedence was that his

\footnotetext{
$25 \quad$ Khumalo, Politics, Power and Production, 79. Etherington, Preachers, Peasants and Politics, 121. Khumalo, Politics, Power and Production, 83-86 Pietermaritzburg Archives Repository (PAR) Secretary for Native Affairs (SNA) I/1/15. R. Mann $28 \quad$ Pietermaritzburg Archive
to T Shepstone. 6 February 1865.

$29 \quad$ Khumalo, Politics, Power and Production, 81
} 
initiative remained fully his: he and Ncaijana initiated and tried to maintain it, and were responsible for its running costs although a government loan was used in establishing it.

The details of the launching of the business have to be read through the words and observations of white partners, participants and onlookers. Nembula often communicated with the government and with suppliers through intermediaries. This strategic mediation means that a whole facet of the experience - its weight to Nembula, his views and intentions - can only be guessed. In first planning the business, inspired by Umvoti, Nembula sourced the mill from a Mr Platt. He pursued the purchase with a determination that surprised Platt:

I had not offered it...I had not in any way induced him to buy from me. Indeed he wanted it rather at too early a date to suit my interests: but nevertheless he got it, and it is now erected and in working order on his premises. ${ }^{30}$

The price asked was £520, which the partners planned to pay off as soon as possible. Once the mill had been purchased, and before it was working, Rood expressed concern about the plan; he felt they did not yet have the managerial experience to get the mill up and running, and would get seriously indebted before it could become profitable.

However, Robert Mann (the "Visitor of Native Institutions" at the time) was interested in the Amanzimtoti project from its inception, and recommended that the government advance a sum of $£ 100$ "on behalf" of Nembula and Ncaijana, to Rood - who, Mann said, would then supervise the erection of the mill, and arrange for the partners to get the necessary training in managing it. ${ }^{31}$ This money would be granted from the same "Reserve Fund" of $£ 5000$ that had provided a seed for starting the production at Umvoti, and was to be paid back. The American Board mission stations were at this time making constant appeals for grants from this fund, on behalf of amakholwa who were starting up small businesses.

Sir Theophilus Shepstone, Secretary for Native Affairs, pronounced that "money cannot be better laid out", and the amount was sent to Rood. ${ }^{32}$ This initial supportive act and sentiment exemplified the colonial administration's early bursts of positivity toward black economic initiatives. Later, requests for a larger amount at an important point in production were denied.

Nembula and Ncaijana, in consultation with Rood, decided to parcel out the £100. Of this $£ 5$ went as an instalment to Platt. The remaining £95 went on employing a team of white workmen, to set the mill machinery in a brick building, and on getting an engineer to put it in motion. The engineer gave a quick few days of training in operating the machinery. Again, Mann watched and relayed the intense preparations:

$30 \quad$ PAR SNA I/1/15, S. Platt to T. Shepstone. April 101865.

31 PAR SNA I/1/15. R. Mann to T Shepstone. 6 February 1865. Mann commented in the 1860s upon various thriving amakholwa farming initiatives. See Bundy, The Rise and Fall of the South African Peasantry, 172-173.

$32 \quad$ PAR SNA, I/1/15, 7 February 1865. 
Nembulo only received three days' instruction in the management of the Machinery from an Engineer, but he visited and examined several of the Sugar Mills in the Neighbourhood and is now able to superintend the works of his own machinery without any extraneous aid. ${ }^{33}$

During March, the workmen were at Amanzimtoti putting up the mill structures, and Nembula needed to get hold of more building materials. Worried about possible exploitation by unscrupulous town traders he approached Platt once more, asking him to order them in Durban and pay for them, until money was freer and he could be repaid: "Unembula applied to me for assistance in procuring iron roofing and timber for his Mill house. He feared imposition being practised upon him by the Durban people, and got me to order the material, he engaging to meet the payments”.

At this point the Amanzimtoti and Umvoti mills were closely linked; Nembula confided to Platt that he was counting on a huge loan he had been promised by the Umvoti planters. $^{34}$ On the strength of the promised money, he became further indebted to Platt, by about $£ 600$, still owing the Government $£ 100$. However, Umvoti itself was struggling and could not spare the money in the end. Platt wrote: "Now... I am informed that such aid will not be forthcoming". ${ }^{35}$ Platt believed that the mill at Umvoti was being used far below its capacity, for too few hours of the day, so that all the cane being grown was being wasted.

Platt was also deep in debt at this point; his financial situation was tied to Nembula's, and he decided he had to begin charging him interest. He approached the government to loan Nembula the large amount he needed, but at a lower interest rate than Platt himself was able to charge. Platt's letters give some sense of the tight personal and financial ties between the two men. From the letters it is unclear whether he himself framed his regard for Nembula in terms of racial condescension, or did so strategically in laying the matter before the government:

Government possibly has spare funds out of the Reserve, for which a less rate of interest would be charged, and this would be a clear advantage to one of the best and most trustworthy natives in Natal. ${ }^{36}$

The government refused, however. Platt was praised for his "liberality", but the hand of financial aid was at this point withdrawn from the entrepreneurs; the minutes stated coldly that Nembula would have to learn a "lesson" from this experience; of the importance of "self-sufficiency". This was ironic in the context of this enterprise - to be viable at all, it required a substantial outlay. No matter what he did at this point, Nembula would not be able to generate it on his own.

33 PAR SNA I/1/15, R. Mann to T. Shepstone, 5 June 1865.

$34 \quad$ PAR SNA I/1/15. S Platt to T Shepstone. 10 April 1865.

35 PAR SNA I/1/15. S Platt to T Shepstone. 10 April 1865.

$36 \quad$ PAR SNA I/1/15. S Platt to T Shepstone. 10 April 1865. 
Despite the debt, production began. In the early months of 1865, many amakholwa in the Amanzimtoti Mission Reserve started farming sugarcane. ${ }^{37}$ The crops must have been grown specifically for processing in Nembula and Ncaijana's mill. However, by early June 1865, when the mill was producing sugar, the crop was not yet big enough to allow production to go ahead at full speed. Nevertheless Mann, and Rood, stated that the outlook was very good. Mann gave a positive report of the Amanzimtoti sugar works:

This little Mill is of very great interest as being the first in the Colony that is owned by Natives and worked entirely by Native hands. About seven tons of sugar will be made during the present season. The power of the Mill is adequate to the manufacture of twelve hundred cwt per day. ${ }^{38}$

The project drew widespread interest, and Mann's report on the milling was published in the Grahamstown Journal for $21^{\text {st }}$ July $1865 .^{39}$

Debt tightened again by 1866, when Platt's financial situation suddenly worsened and his agent in town began pressuring him once more. He wrote to Rood in desperation:

Before I go to the expense of obtaining security from Nembula \& Ncaijana, I wish to try for a settlement of my [debt] by submitting to a sacrifice. You know all about my reasons for disturbing these our friends, and why I want money.

They owed me at Christmas $£ 515$ - Five Hundred and Fifteen Pounds. Now this amount at $12 \%$ will be like a great weight on their shoulders - and if I can not receive it when I sorely need it, it will be as nothing to me. ${ }^{40}$

Platt extended the date by which the partners could repay him. Nembula and Ncaijana petitioned Mr G Cato of Durban, (who was then managing the Umvoti mill), to loan the large sum of $£ 250$ for the next year, if Nembula's land could be mortgaged as security. The Lieutenant Governor duly gave permission for the land to be mortgaged, and production could continue with the debt held off for the moment.

Little information can be found on the everyday running of the mill. Nembula's family took on some of the work of growing cane to supply it. In Ephraim Nembula's 1941 account, the missionaries "brought in tractors for ploughing, after Nembula's children were injured." 41

The partners intended to break into the international market. In 1867 Nembula and Ncaijana "sent samples of their sugar to the Paris Exhibition"; ${ }^{2}$ Nembula was hoping to reach much further than Natal, where the market was already oversaturated.

\footnotetext{
37 PAR SNA I/1/15. S Platt to T Shepstone. 10 April 1865.

PAR SNA I/1/15. R Mann to T Shepstone. 5 June 1865.

R.F. Osborn. Valiant Harvest: The founding of the Aouth African Sugar Industry, 1848-1926.

(Durban: The South African Sugar Association, 1964) 136.

$40 \quad$ PAR SNA I/1/16. S Platt to D Rood. 20 February 1866.

41 KCC, Uncat. MSS, in “Steel Drawers”, 8639, Ephraim Nembula to Killie Campbell, c.1940.

42 Osborn. Valiant Harvest, 136.
} 
In about the middle of 1869, Nembula was "unanimously chosen" by the Amanzimtoti church as "the most suitable man for their pastor". He could not accept ordination, because he was still managing the mill, and this consumed his time. ${ }^{43}$

The American Board missionary William Ireland writing a potted history of the mission for its jubilee mentioned the initiative, giving some insight into the division between Nembula's preaching and farming commitments:

...he was so immersed in sugar making, and so burdened with debts growing out of the enterprise, that he could not then entertain the proposition, nor did the Mission think it wise for him to do so under the circumstances. When, however, these debts were so far cancelled, as no longer to present a serious objection, Nembula expressed his willingness to enter upon these duties as soon as the necessary arrangements could be made. $^{44}$

Nembula subsequently accepted ordination in August 1872, so by then he may have recovered from a serious load of debt and managerial obligations related to running the plant. It is unclear whether Nembula shifted to preaching because the sugar production was foundering, or whether he kept both jobs running for a time.

Certainly by the late 1870s, production was becoming less and less viable. Though the details of the closure are unknown, Osborn claimed that after 1878 there was no record of a mill at Amanzimtoti. ${ }^{45} 1878$ was a very bad drought year - and it is possible that this was the final straw for the struggling enterprise. The story of the life of the mill clearly showed how expensive sugar production was.

The different ways in which the project has been remembered and forgotten are interesting to note: when Amanzimtoti was buzzing with the work surrounding this mill, the American missionaries mentioned it often in their letters. By contrast, notwithstanding Ireland's reference to the mill above and other mentions of it, the book histories of the American Board Mission that have been written and/or produced by the American Board generally do not mention the enterprise. Even in the brief missionary biographies of Nembula himself, this very ambitious project of his does not feature. As we might expect, before the project foundered, the missionary David Rood, who was resident at Amanzimtoti when the project was underway, indicated the project was itself a "fruit" of the mission. In much the same way, Aldin Grout commented on farming and economic expansion at Umvoti in $1861 .{ }^{46}$ The sad end of some of these ventures was a failure shared by the missionaries; though the impact was negligible for them by comparison, many missionaries had been involved in making representations to government for money, to start up or sustain the projects.

\footnotetext{
$43 \quad$ William Ireland, Jubilee of the American Mission in Natal, 42.

$44 \quad$ William Ireland, Jubilee of the American Mission in Natal., 42.

$45 \quad$ Osborn, Valiant Harvest, 136.

46 Bundy, The Rise and Fall of the South African Peasantry, 172.
} 
Nembula's grandson and heir Ephraim wrote to Dr Killie Campbell in 1941, about his family. This was how he described the project and its remains, seventy years after the heyday of the Amanzimtoti sugar production: "Nembula and Cayijana Mkhwanazi were the head of the development, however Nembula left with [his eldest son] Henry for preaching. The ploughing was closed and the machines were moved to Illovo; I still have the pot that was used to burn the sugar cane here at home." 47 The letter shows that Nembula's descendants recalled the initiative as an object of pride, and evidence of development at the time, though only its remains persisted. Ephraim Nembula felt that this was all "because of Mbalasi" and her moment of conversion. Njabulo Makhanya, a relative, today describes the initiative as having brought Nembula considerable recognition during his life.

As a minister - [the early family history] means a lot to me, because Nembula and his mother Mbalasi were the founders of the church: founders and pillars of the church. Because Nembula was one of the first ministers [...] and Nembula had a sugar milling machine [...] So he was a very prominent person amongst his kinsmen. ${ }^{48}$

In the beginnings of the project, in 1865 when the mill was being started up, Rood wrote that:

Two of our men are justly entitled to the credit of taking the lead on the country in the work of starting by native enterprise alone the first establishment which deserves to be called a manufactory. Their sugar mill was completed and set in operation about six weeks ago since which time the little valley north of the station has witnessed a visable [sic.] triumph of Christianity and civilisation which the most sceptical cannot gainsay. Men with black skins who a few years ago were naked boys...are now competing with the white man in manufacturing sugar in a steam mill of their own from canes of their own cultivation and without any superintendence in the work. ${ }^{49}$

To Rood, the mill clearly represented an admirable flowering of the "civilising mission"; capitalism emerging out of Christianity. As has been pointed out by among others Myra Dinnerstein in her study of the "American Zulu Mission", the American Board missionaries held a belief, inherited from New England Puritanism, that "material success was a reflection of inner godliness."50

To what extent has the venture been recorded? In a glancing mention in Historic Natal and Zululand (1948), H.C. Lugg mentioned "the opening of a

\footnotetext{
47 KCC, Uncat. MSS, in “Steel Drawers”, 8639, Ephraim Nembula to Killie Campbell, c.1940.

$48 \quad$ Interview with Njabulo Makhanya, Weds 28 ${ }^{\text {th }}$ November. 2007. 11: 40, Durban.

49 ABCFM 15.4, 7, D Rood to R Anderson, July 31, 1865, Cited in Etherington, Preachers, Peasants and Politics, 120-121.

50 Dinnerstein, The American Board Mission to the Zulu, 12.
} 
small sugar mill by two Natives which they operated for a time."51 He described this initiative as having been the "first fruits" of the agriculturallyoriented Amanzimtoti Seminary (later Institute) which had opened in 1863.

By the time the sugar milling closed, Nembula was supporting a family of at least six; his daughter Katie and son Hiram had been born in the late 1860s. ${ }^{52}$ He became the one of the seven African pastors first ordained in the American Board (before 1880), mentioned in missionary writings. The others were Rufus Anderson (formerly Mguzana Mngadi, ordained at Umzumbe, who returned to polygamy after seven years much to the horror of the missionaries), Msingapansi Nyuswa of Imfume, James Dube of Inanda - all three ordained in 1870; Benjamin Hawes posted at Itafamasi on his ordination in 1872 and Mbiyana Ngidi, a cousin of William Ngidi who worked with the Anglican Bishop of Natal William Colenso.

After the milling venture, Nembula tried different means of work. At the time, as a minister of the ABM, he along with many others had a difficult relationship with the American missionaries who put pressure on church members, especially from the late 1870s, to completely avoid practices like polygamy and, (as became particularly problematic for Nembula), the payment of lobola, which he completely avoided, refusing to accept lobola on his daughters' marriages. ${ }^{53}$

There are traces connecting Nembula to a wide network of amakholwa, some of whom returned to "heathen survivals" like lobola and polygamy. The mill owned by Nembula was named "Ncaijana", apparently in honour of his partner. ${ }^{54}$ A second mill, according to Osborn, was being operated at Adams Mission in the late 1860s-1870s. ${ }^{55}$ This one was identical to the other, and apparently stopped operations at around the same time: at Adams there were (excluding the Imfume mill which started up in about 1874) " 2 steam mills each with 6 h.p. steam engine clarifiers, batteries, evaporators, and centrifugals"56

The second Amanzimtoti mill was called "Fumana" - which suggests it may have been in some way connected to another early convert at Amanzimtoti, Famana. Famana was one of those whose return to "heathen survivals" infuriated the missionaries, in the 1870s and 1880s when missionary/convert conflict over these issues was intensifying. In 1887, the American Board missionary William Ireland was writing indignantly to Henrique Shepstone, the then Secretary for Native Affairs, to try and shore up missionary authority within the Amanzimtoti mission reserve:

\footnotetext{
$51 \quad$ H. C. Lugg, Historic Natal and Zululand, (Pietermaritzburg: Shuter \& Shuter,1949) 12.

52 PAR SNA I/1/115 543/1889: Hiram Nembula: request for new exemption papers; PAR SNA

I/1/159 830/1892. Katie Nembula

$53 \quad$ Natal Native Commission (NNC). Evidence of “Nambula, Dronk Vley (Spokesman) and Makubula, Amanzimtote Mission Station”. 13 ${ }^{\text {th }}$ February, 1882. 169-176.

$54 \quad$ Osborn. Valiant Harvest, 135.

$55 \quad$ Osborn. Valiant Harvest, 135.

$56 \quad$ Osborn. Valiant Harvest, 135.
} 
There is a man named Famana, living on this Reserve who was a baptized Ikolwa, nearly 40 years ago, when Dr Adams first settled at Amanzimtote. He has for many years, been excluded from Church privileges for adhering to forbidden customs, \& he has recently added to his other offences that of Polygamy, in spite of having originally been married according to Christian rites. When the other titles were issued some 29 years ago, he obtained a title to some 20 acres of land, on this Reserve, but nearly 3 miles away from the Mission Station. Here he has lived for many years. After he took another wife Mr Robbins, as the missionary in charge, ordered him not to cultivate outside his own land - He has persisted in doing so, though repeatedly warned. When in town last week, I mentioned these facts to Messrs Rood \& Pixley, \& we all feel that he ought not to be allowed to set the missionary at defiance. I now ask whether the Magistrate will be sustained, in compelling Famana to comply with this demand...There is a similar case at Ifumi [Imfume] - A man who had been a church member for years - and now has gone into Polygamy... 57

The Secretary for Native Affairs decided not to give the missionaries legal backing, as these titles had often allocated to people the land they had been living on when the missionaries first arrived:

All three Natives were on the lands I think when the lands were set apart as Mission Reserves and the Title Deeds say that the Natives in occupation were not to be disturbed in their occupation... The land was set apart for Mission purposes in order to enable the Missionaries to have a fixed Native Population to work among. ${ }^{58}$

Land was becoming an ever more pressing problem. While missionaries shrilly petitioned the state to whip away material security from under polygamists (Famana's trespassing was clearly not the biggest part of Ireland's problem with him), some like Nembula had their sights set on much larger plots of land than the mission stations could offer.

Nembula like many amakholwa bid for crown land at public auctions. His evidence to the Natal Native Commission of 1881-2 reflected the difficulties of raising sufficient money, and Nembula's view on the remedy:

When many Englishmen in this country were learning to creep, they got land at 5s. per acre and had ten years to pay it in. It is now 10s. per acre, and those white men learned to run and we are still crawling. We think that the price, while we are still babies, should be the same as when the white men were babies. There should be an officer appointed to protect us and act for us in purchasing land. ${ }^{59}$

\footnotetext{
$57 \quad$ PAR SNA I/1/104 24/1888, William Ireland to Henrique Shepstone, 22 December 1887.

$58 \quad$ PAR SNA I/1/104 24/1888, Attorney General to SNA, 13 February 1888.

59 Natal Native Commission (NNC). Evidence of "Nambula, Dronk Vley (Spokesman) and Makubula, Amanzimtote Mission Station”. 13 ${ }^{\text {th }}$ February, 1882. 169-176.
} 
Stephanus Mini of Edendale, in his Evidence to the Commission, complained of the same injustice and called for the same solution. ${ }^{60} \mathrm{~A}$ few months after giving this evidence, Nembula was at work securing a plot of land which had been advertised for public auction in the Government Gazette: "Lot S-7", a farm in the area known as "Dronk Vlei", where he had been living (according to anecdote the area got its name because the flowers growing in the vlei or wetland there, if eaten, make cattle disorientated, as if drunk). The plot was large (two thousand acres), and was placed on the Upper Umkomazi river, "Bounded on the North by the Umzimkulu River, South by Crown Land, East by Lots 8, 9 and Crown Land and West by Native Location No. 1". ${ }^{1}$ Nembula paid the survey fee on the day of the auction. The property was signed over to him on the $30^{\text {th }}$ December 1882, and on this date he paid the first of ten annual instalments - $£ 100 .^{62}$ His plan was to pay off subsequent instalments through his transport-riding business, and the farm was intended as an inheritance for his oldest surviving son, Norman Sidney Nembula, on which to support a family. ${ }^{63}$

However this plan was never realised: before he could earn enough to pay any further instalments, and very soon after he bought the farm at Dronk Vlei, Nembula's span of oxen died of lungsickness. ${ }^{64}$ After the blow, Nembula became ill, and died of consumption on the $25^{\text {th }}$ of April 1886, at Newtonville, where he had preached for many years. He was buried at Newtonville. ${ }^{65}$

After his death a controversy unfolded over the land he had purchased. Several men in the area around Dronk Vlei came forward and claimed Nembula had approached them or their fathers to assist him in paying the first instalment. According to them they were never given the sections of the land promised them in return. ${ }^{66}$

Years of correspondence followed between Nembula's children and the colonial government. Six months after their father's death, it became clear that Norman Nembula was "at his wits' end" over the $£ 300$ pounds still owing on Dronk Vlei. Advised by the American missionary William Ireland, he approached the Surveyor General and the Secretary for Native Affairs. ${ }^{67}$

\footnotetext{
$60 \quad$ Evidence, p 135. Quoted in Etherington, Preachers, Peasants and Politics, 167.

PAR SNA I/1/99, 441/1887, David Smith- Government Surveyor. Diagram and details of surveyed land, June 1882.

62 PAR SNA I/1/99, 441/1887, "Certificate of Sale and Purchase of Crown Lands known as Lot S-7, Ixopo in the County of Pietermaritzburg, Colony of Natal”. 30 December 1882.

63 PAR SNA I/1/99, 441 of 1887.Statement of Norman Sidney Nembula before Resident Magistrate of Ixopo Division. 18 March 1887.

$64 \quad$ PAR SNA I/1/99, 441/1887, Statement of Norman Sidney Nembula, 18 March 1887.

$65 \quad$ PAR SNA I/1/99, 441/1887, Statement of Norman Sidney Nembula, 18 March 1887.

66 Four men signed statements at the offices of the Ixopo Regional Magistrate to this effect. However whether Norman Nembula acknowledged their claim in any way is uncertain. PAR SNA I/1/99. $845 / 1887$.

$67 \quad$ SNA I/1/99 ref 441/1886, Chadwick to SNA.
} 
The debates between the colonial officials about the Nembulas' land are revealing. Firstly, they had not encountered a case like this before; it was the first time that a large plot of Crown land had been bought by a black man who was not "exempt" from the operation of native law, and had died without a will; the payments were badly in arrears due to his death, and almost all of his children had gotten exemption from native law.

The government officials who dealt with the Nembulas' letters clearly thought this posed a legal and political conundrum. In December 1886, the Executive Council asked the Colonial Engineer to "draft an instruction for the guidance of the Surveyor General in dealing with cases of arrears" ${ }^{\prime \prime 8}$ Later, when discussing the problem brought forward by Norman Nembula, the Secretary General wrote "Whatever decision is arrived at in this case will be used as a precedent for others who may be in arrears." ${ }^{\circ 9}$ Should the plot be partitioned, leaving a portion to the original owners - considered a more "liberal" alternative to confiscation, for black families who could not pay more instalments? If this approach was taken, the Surveyor General fretted, would whites purchasing the other portions not be disadvantaged, because the black family would choose the "eye" of the land, where the water source was located? The Nembulas asked that a decision be deferred until their brother John Mavuma had returned from his medical studies in America.

Colonial officials' encounters with members of the family, along with other similar cases, also possibly had an impact on colonial law. Act number 7 of 1895 stated that "If a native, under native law, dies intestate, his estate is to be administered under the code [of Native Law] of 1891, even though his heirs, or any of them, hold letters of exemption from native law, and the Supreme Chief [SNA] may define the customs and usages and regulate the procedure in the administration of any such estate." 70

What do we make of this? The Nembulas' experience was not singular. Yet, given that theirs was seen as an unusual situation in the 1880s and the specific wording of the act, along with other cases theirs likely informed the law.

Nembula Duze held the steady ministry suggested by missionary records in tension with a vertiginous life of entrepreneurship, risking his livelihood repeatedly in his attempt to secure a solid one. In many ways, and for those who remember Nembula today, he and his family were exemplary of and helped early on to bring into existence a way of living. What is emphasised in oral and written sources mentioning them is that there was something significant about the precedence of the actions taken by Mbalasi, by Nembula, and by his son John Mavuma Nembula - as first convert in Natal, second convert, the first black man to own a sugar mill, the first Zulu doctor. Partly by reading through and against a colonial archive, we can begin to guess at how that "first-ness", the act of making onesself a "first fruit", was experienced and mobilised by the members of a family in a pressurized time.

\footnotetext{
$68 \quad$ PAR SNA I/1/99, 441/1886.

$69 \quad$ PAR, SGO I/1/99, 29 Oct 1888.

70 Courtenay Ilbert, "South Africa”, Journal of the Society of Comparative Legislation, Vol. 1 (1896 - 1897), pp. 90-98, p. 96
} 
